\title{
EFFECT OF FOLIAR SPRAY WITH POTASSIUM AND MAGNESIUM ELEMENTS ON NUTRITIONAL STATUS, PRODUCTIVITY AND FRUIT QUALITY OF "ANNA" APPLE TREES UNDER WATER DEFICIT CONDITIONS
}

\author{
M. A. M. Soliman and H. M. Abo-Ogiela \\ Deciduous Fruit Trees Research Department, Hort. Res. Instit. ARC. Giza, Egypt.
}

Received: Jan. 1, 2017

Accepted: Jan. 22,2017

\begin{abstract}
This study was conducted during 2015 and 2016 growing seasons at a private orchard at El-Nubaria region, El-Behira Governorate, Egypt. The objective of this study was to investigate the response of "Anna" apple trees budded on Malus rootstock to three amounts of irrigation water using drip irrigation system; $l_{1}$ : like irrigation water amount the local farmers in the studied regions ( control, $15.584 \mathrm{~m}^{3} /$ tree/year) , $I_{2}: 75 \%$ from the control ( 11.657 $\mathrm{m}^{3} /$ tree/year) and $\mathrm{I}_{3}: 50 \%$ from the control $\left(7.792 \mathrm{~m}^{3} /\right.$ tree/year), foliar spray included four treatments :W (tap water without $K$ and $M g$ ), $K, M g$ and $K+M g, 4$ times applications, starting after fruit set, and the others 15 days intervals ( $K$ added as potassium sulphate at rate $2 g / L$, $\mathrm{Mg}$ added as magnesium sulphate at rate $2 \mathrm{~g} / \mathrm{L}$ ) and their interactions on vegetative growth, water relations, leaf chlorophyll and mineral contents, yield and fruit quality of "Anna" apple trees. The experimental trees had the same volume and shape and were grown in a sandy loam soil, spaced at $5 \times 5$ meters apart and received the normal culture practices commonly adopted for this region.
\end{abstract}

The main results can be summarized as follows:

Foliar application of investigated nutrients increased leaf area, specific leaf weight, leaf chlorophyll, leaf- $N, P, K$ and $M g$ contents, fruit set, fruit weight, yield, fruit firmness, total soluble solids\% and anthocyanin compared to the unsprayed trees in the two growing seasons. The application of $K+M g$ gave the highest values, the application of $K$ alone was superior to the individual application of Mg. On the contrary, foliar spray with these nutrients didn't show a significant differences on fruit juice acidity in the two seasons. Also, it was observed that, $K$ and $(K+M g)$ treatments significantly increased total water content and decreased water deficit percentage in leaves compared to $\mathrm{Mg}$ or control (W). Mg treatment decreased total water content compared to the control.

As for the effect of irrigation rates, the results revealed that $\left(I_{1}\right)$ treatment was superior for leaf area, total water content, leaf chlorophyll reading and leaf- $N, P, K$ and $M g$ contents. Also, fruit set as well as yield and fruit weight as compared to the other treatments in the two seasons. $I_{2}$ treatment recorded the highest values of specific leaf weight in the two seasons and total soluble solids in the second one. On the other hand, $\left(I_{3}\right)$ treatment gave the highest significant value of water deficit, fruit firmness and anthocyanin in the two seasons, and total soluble solids in the first season for "Anna" apple.

The interaction effects between the foliar application of investigated nutrient and different irrigation treatments revealed that, $(K+M g) x l_{1}$ gave the highest significant mean values of leaf area, total water content and leaf- $P$ content in the second season, fruit weight in the first one, also, leaf- $N$ and $K$ contents as well as yield per tree and total yield (ton/fed) in both seasons, while the interaction between $(\mathrm{K}+\mathrm{Mg})$ and $\mathrm{I}_{3}$ gave the highest significant values of total soluble solids\%, fruit juice acidity and anthocyanin in the first season, and fruit firmness in the second one.

It could be recommended from this study that, Potassium and magnesium fertilizers have improved vegetative growth, yield and fruit quality of "Anna" apple and increasing water use 
efficiency (WUE) under using a lot of water supply with no offering to water deficit condition. Sprayed "Anna" apple trees with $\mathrm{Mg}$ and $\mathrm{K}$ gave the best results as compared to the individual applications.

Key words: Irrigation, Mg, K, "Anna" apple, leaf chemical composition, water relation, yield, fruit quality.

\section{INTRODUCTION}

Anna apple (Malus domestica, Borkh) is a low chilling requirement cultivar spreading in many tropic and subtropics areas. It is considered as one of the most important commercial cultivars planted in Egypt. It is well known that deficit water is one of many factors which have a negative effect on apple growth, yield and fruit quality. The degree of these effects depends on its impact on the plant physiological and biochemical, as well as molecular biological process and the ability of plant to adapt to drought stress (Atkinson et al., 2000; Massonnet et al., 2007). The drought stress has an influence on vegetative growth and total chlorophyll contents (Mikhael, et al., 2010), specific leaf weight (dry matter per unit leaf area-SLW) (Pasban Eslam et al., 2000), relative water content (Fanaei et al., 2009) ), leaf water and osmotic potential (Chhabra et al., 2007). Ali et al., (1998) and Khalil et al., (2000) who concluded that adequate water supply for apple trees is an important factor for maximizing it's production, these it may be attributed to the greater amount of synthesized metabolites which can be considered as a final result of improving all physiological processes including nutrient uptake (Khalil, 1991). Khalil et al., (2000) on apple, Mohamed (2003) on olive and El-Seginy (2006) on apricot, indicated that fruit quality was found to be better using a lot of water supply than water deficit conditions. In recent studies it became well established that mineral elements have a noticeable effect on increasing water use efficiency and draught resistance and flooding of cultivated plants (Soliman, 2003). This kind of research on plant water relationships has great value for agriculture in arid and semi-arid regions.
Potassium plays vital role in: photosynthesis, protein synthesis, control of ionic balance, regulation of plant stomata and water use, activation of plant enzymes and, many other processes (Marschner, 1995 and Reddya, et al., 2004). Hence, under drought conditions, the accumulation of potassium increases in plant tissues that improves uptake of water from soil to plants. Increased application of $\mathrm{K}$ has been shown to enhance photosynthetic rate, plant growth and yield in different crops under water stress conditions (Yadav, et al., 1999 and Egilla, et al., 2001 ). In addition, El-sherif et al,. (2008) reported that, spraying "Golden Japanese" plum by four potassium fertilizer sources at bud burst, after fruit set and one month after fruit set increased significantly fruit set, yield, fruit weight and size, as well as total sugar and potassium percentages, while decreased fruit drop percentage in comparison with the control treatment. In addition, the tested treatments increased total carbohydrates and leaf macro-elements content.

Magnesium ( $\mathrm{Mg}$ ) on the other hand, is an essential element for chlorophyll molecule structure that regulates photosynthesis process. Also, it acts an activator of many enzyme systems involved in carbohydrate metabolism and synthesis of nucleic acids. Furthermore, it plays an essential role in the biological activity of ATP (Jones et al., 1991). Many investigators have started to study magnesium nutrition and determination of magnesium needs of economically important crops in Egypt (Salem 2007 and El-Fouly et al., 2012). Generally, the influence of magnesium on yield and fruit quality was reported by ElSafty and Rabii, (1998) on Washington navel orange tree and Abou Aziz et al., 
(2000), and Mostafa et al., (2007) on banana plants. They mentioned that magnesium fertilization improved yield and fruit quality of the abovementioned fruit species. On the other hand, Soliman, (2003), concluded that, foliar spray with nutrient solution including $\mathrm{Fe}, \mathrm{Mn}, \mathrm{Zn}$ and $\mathrm{Mg}$ could increase plant drought resistance through increasing bound water content, osmotic pressure of the cell sap and organic matter percentage of some deciduous fruit tree leaves leading to increasing water use efficiency of the plants.

The purpose of this study was investigate the effect of foliar application of either potassium, magnesium as well as their combinations under shortage in irrigation water on vegetative growth, fruit set, leaf mineral content, yield and fruit quality of 'Anna' apple trees grown in a sandy loam soil located at El-Nubaria region, El-Beheira governorate, Egypt.

\section{MATERIALS AND METHODS}

A field experiment was carried out during the two successive seasons of 2015 and 2016 on eight years old "Anna" apple trees (Malus domesticaL. Borkh) budded on Malus communis rootstock spaced at $5 \times 5$ meters apart and received the normal culture practices commonly adopted for this region and the drip irrigation was used. The trees were grown on sandy loam soil in a private orchard located at El-Nubaria, ElBeheira governorate, Egypt. The chemical and physical analysis of experimental soil were indicated in Tables 1 and 2.

Split plot design was used, treatments replicated three times every replicate was two trees. The foliar spray were randomized in the main plots and irrigation levels in the sub - plots. Foliar spray included four treatments :W (tap water), $\mathrm{K}, \mathrm{Mg}$ and $\mathrm{K}+$ $\mathrm{Mg}$, spraying was replicated 4 times, starting after Fruit set, at 15 days intervals. Irrigation treatments included three levels $: l_{1}: 100 \%$ (control) like practice by the local farmers in the studied regions, $\mathrm{I}_{2}: 75 \%$ ( control), and $I_{3}: 50 \%$ ( control). $K$ added as potassium sulphate $\left(48 \% \mathrm{~K}_{2} \mathrm{O}\right)$ at rate $2 \mathrm{~g} / \mathrm{L}, \mathrm{Mg}$ added as magnesium sulphate at rate $2 \mathrm{~g} / \mathrm{L}$. All agricultural practices were carried out according to the crop and the area except the studied treatments which abovementioned. The daily amount of irrigation water as liters per tree for each level in both seasons are shown in Table (3).

Table 1.Chemical properties of the experimental site:

\begin{tabular}{|c|c|c|c|c|c|c|c|c|c|c|c|}
\hline \multirow{2}{*}{$\begin{array}{l}\text { Soil } \\
\text { depth } \\
\text { (c m) }\end{array}$} & \multirow[t]{2}{*}{$\mathrm{pH}$} & \multirow[t]{2}{*}{$\begin{array}{c}E C \\
\text { (ds/m) }\end{array}$} & \multirow[t]{2}{*}{$\begin{array}{l}\text { O.M } \\
(\%)\end{array}$} & \multirow[t]{2}{*}{$\begin{array}{c}\mathrm{CaCO}_{3} \\
(\%)\end{array}$} & \multicolumn{4}{|c|}{$\begin{array}{c}\text { Soluble cations } \\
\text { (Meq/L) }\end{array}$} & \multicolumn{3}{|c|}{ Soluble anions (Meq/L) } \\
\hline & & & & & $\mathrm{Na}^{+}$ & $\mathrm{Ca}^{+2}$ & $\mathrm{Mg}^{+2}$ & $\mathrm{~K}^{+}$ & $\mathrm{HCO}_{3}{ }^{-}$ & $\mathrm{Cl}^{-}$ & $\mathrm{SO}_{4}^{-\prime}$ \\
\hline $0-30$ & 8.10 & 1.72 & 0.85 & 19.4 & 4.26 & 8.61 & 2.80 & 1.59 & 1.40 & 1.80 & 14.10 \\
\hline $30-60$ & 8.14 & 1.83 & 0.69 & 19.2 & 5.46 & 8.27 & 2.94 & 1.71 & 1.30 & 1.60 & 15.40 \\
\hline Mean & 8.12 & 1.77 & 0.77 & 19.3 & 4.86 & 8.44 & 2.87 & 1.65 & 1.35 & 1.70 & 14.75 \\
\hline
\end{tabular}

EC: were measured in the extract of soil paste at $25 \mathrm{C}^{0}$, $\mathrm{pH}$ : was measured in 1:2.5 (soil water suspension)

Table 2. Physical properties and water constants of the experimental site:

\begin{tabular}{|c|c|c|c|c|c|c|c|c|}
\hline \multirow{2}{*}{$\begin{array}{l}\text { Soil } \\
\text { depth } \\
(\mathrm{cm})\end{array}$} & \multicolumn{4}{|c|}{ Particle size distribution } & \multicolumn{3}{|c|}{ Soil moisture characteristics } & \multirow{2}{*}{$\begin{array}{c}\text { Bulk } \\
\text { Density } \\
\left(\mathrm{g} / \mathrm{cm}^{3}\right)\end{array}$} \\
\hline & $\begin{array}{l}\text { Sand } \\
\text { (\%) }\end{array}$ & $\begin{array}{l}\text { Silt } \\
(\%)\end{array}$ & $\begin{array}{l}\text { Clay } \\
(\%)\end{array}$ & Soil texture & F.C (\%) & WP (\%) & AW (\%) & \\
\hline $0-30$ & 69.91 & 18.07 & 12.02 & \multirow[t]{3}{*}{ Sandy loam } & 11.8 & 4.7 & 7.1 & 1.36 \\
\hline $30-60$ & 67.89 & 18.63 & 13.48 & & 12.8 & 4.7 & 8.1 & 1.34 \\
\hline Mean & 68.90 & 18.35 & 12.75 & & 12.3 & 4.7 & 7.6 & 1.35 \\
\hline
\end{tabular}

FC: Field capacity, WP: wilting point, AW: available water. 
Table 3. The daily amount of irrigation water as liters per tree for each level.

\begin{tabular}{|c|c|c|c|c|c|c|c|c|c|c|c|c|c|}
\hline \multirow{2}{*}{$\begin{array}{c}\text { Irrigation } \\
\text { levels }\end{array}$} & \multicolumn{12}{|c|}{ Months (liter/tree/day) } & \multirow{2}{*}{$\begin{array}{c}\text { Total } \\
\left(\mathrm{m}^{3} / \text { tree/year }\right)\end{array}$} \\
\hline & Jan. & Feb. & Mar & April & May & June & July & Aug. & Sept. & Oct. & Nov & Dec. & \\
\hline $\mathrm{I}_{1}$ & 6 & 36 & 48 & 52 & 72 & 60 & 60 & 72 & 52 & 32 & 16 & 6 & 15.584 \\
\hline $\mathrm{I}_{2}$ & 4 & 27 & 36 & 39 & 54 & 45 & 45 & 54 & 39 & 24 & 12 & 4 & 11.657 \\
\hline $\mathrm{I}_{3}$ & 3 & 18 & 24 & 26 & 36 & 30 & 30 & 36 & 26 & 16 & 8 & 3 & 7.792 \\
\hline
\end{tabular}

Measurements and determinations: 1- Some soil chemical and physical properties:-

The studied soil chemical characteristics such as soil reaction $(\mathrm{PH})$ values were determined in 1:2.5 soil water suspension. Total soluble salts were measured by electrical conductivity (EC) apparatus in the saturated soil paste extract. Soluble cations and anions $\left(\mathrm{Ca}^{++}, \mathrm{Mg}^{++}, \mathrm{Na}^{+}, \mathrm{K}^{+}, \mathrm{CO}_{3}^{--}\right.$ , $\mathrm{HCO}_{3}{ }^{-}$and $\mathrm{Cl}^{-}$as meq/L ) were determined in soil paste extract (Jackson ,1967). $\mathrm{So}_{4}{ }^{-}$ as $\mathrm{meq} / \mathrm{L}$ was calculated by the difference between cation and anions .

The studied physical characteristics and soil water constants were determined according to the (Klute, 1986).

\section{2- Leaf area and specific leaf weight:}

10 mature leaves were sampled in mid August to determine leaf area $\left(\mathrm{cm}^{2}\right)$ by using a leaf area meter Model Li-core 3100 areameter, and dry weight was recorded after drying at $70^{\circ} \mathrm{C}$ for $42 \mathrm{~h}$., then specific leaf weight was calculated as $\mathrm{mg} / \mathrm{cm}^{2}$ according to (Ferree and Forshey, 1988).

\section{3- Leaf mineral content:}

Leaf samples consisted of 30 leaves of each replicate was collected from the tested apple trees, at mid August, of both seasons. Leaf samples were taken from the middle part of current shoots, washed several times with tap water, rinsed into distilled water and dried at $70^{\circ} \mathrm{C}$ to a constant weight. The dried leaves were ground and digested with sulphoric acid and hydrogen peroxide according to the method described by
Evenhuis and DeWaard, (1980). Nitrogen was determined by the microkjldhel Method according to Jakson, (1967) and Phosphorus was determined colorimetrically according to Murphy and Riley, (1962). The leaf-K and $\mathrm{Mg}$ content were determined by flame photometer E.E.L. Model (Jackson, 1967).

\section{4- Some measurements : \\ 4- 1- Total water content: Total water} content was estimated by drying a known weight of the cleaned fresh green leaves in glass vials in an oven adjusted at $85{ }^{\circ} \mathrm{C}$ until constant weight, total water content was calculated by the following equation :

Total water content $(\%)=$

$$
\frac{\text { Fresh weight }- \text { dry weight }}{\text { Fresh weight }} \times 100
$$

4- 2- Water deficit: 10 discs about 1 $\mathrm{cm}^{2}$ in diameter were cut from the mature leaves, weighted flooded into distilled water for some hours until they attain equilibrium ,reweighed and oven dried at $85^{\circ} \mathrm{C}$ for 24 hours to reach a constant weight. Water deficit were calculated as (Barrs,1968) :

Water deficit $=$

$$
\frac{\text { Turgid weight }- \text { field weight }}{\text { Turgid weight }- \text { oven dry weight }} \times 100
$$

\section{4- 3- Leaf total chlorophyll content} (SPAD unit): leaf chlorophyll reading was recorded using minolta chlorophyll meter SPAD-502(Minolta camera. Co., LTD Japan) at the field in mid August. The average of ten readings was taken on the middle of leaves from all over the tree circumference. 


\section{5- Final Fruit Set and yield:}

Two main branches from two direction (east and west) of each tree were chosen and tagged in March of the two experimental seasons, the number of flowers was recorded and those set fruits on the selected branches were counted for calculating the percentage of fruit set according to this equation:

Fruit set $\%=$

$$
\frac{\text { Number of set fruitlets }}{\text { Number of opened flowers }} \times 100
$$

Yield as weight $\mathrm{kg}$ of fruits per tree was recorded at harvest time ( $3^{\text {rd }}$ week of June.). Furthermore, the yield per fed in ton was estimated by multiplying number of trees /fed. and average tree yield. Water use efficiency (WUE) kg/m3 was calculated according to Michael et al., (2010) by the following equation:

WUE $(\mathrm{kg} / \mathrm{m} 3)=\frac{\text { yield }\left(\frac{\mathrm{Kg}}{\mathrm{fed}}\right)}{\text { water applied }\left(\frac{\mathrm{m} 3}{\mathrm{fed}}\right)}$

\section{6- Fruit Physical and Chemical Properties:}

At harvest time $3^{\text {rd }}$ week of June, fruit weight (gm) was determined, fruit firmness(I $\mathrm{b} /$ inch $^{2}$ ) was measured by fruit pressure tester on the two opposite sides of the fruit. Total soluble solids (\%) of the juice was determined using a hand refractometer. Titrable acidity (\%) was determined by the titration against $(0.1 \mathrm{~N}) \mathrm{NaOH}$ (A.O.A.C., 1981). Anthocyanin was determined (mg/100 $\mathrm{g}$ fresh weight peel) according to Rabino et al. (1977).

\section{7- Statistical Analysis:}

All data collected were subjected to the standard statistical analysis following the proceeding described by Gomez and Gomez (1984) using the computer program (IRRISTAT). LSD was done at $5 \%$ for comparison between means.

\section{RESULTS AND DISCUSSION 1. Vegetative growth:}

\subsection{Leaf area and specific leaf weight:}

Data pertaining to leaf area and specific leaf weight of "Anna" apple trees as affected by foliar application with nutrients $(\mathrm{K}, \mathrm{Mg}$, and $\mathrm{K}+\mathrm{Mg}$ ) and irrigation treatments as well as their interactions are presented in Table (4).

It was observed that foliar application treatments with nutrients significantly increased leaf area of "Anna" apple trees in the two seasons compared to the control. The effect of three spray treatments can be arranged in a descending order from $(\mathrm{K}+\mathrm{Mg}), \mathrm{K}$ to $\mathrm{Mg}$. With respect to specific leaf weight it can be noticed a significant increase of the $(\mathrm{K}+\mathrm{Mg})$ treatment compared to the untreated ones (control) in the two seasons. Among to foliar application with $\mathrm{K}$, $\mathrm{Mg}$, and $(\mathrm{K}+\mathrm{Mg})$ there were no significant variation. The enhancement of vegetative growth by application of $\mathrm{K}$ may be due to its vital contribution in several metabolic processes in plants, and its role on assimilating the photosynthetic reaction (Marschner, 1994). These results are in line with those stated by Zayan et al., (2006) on "Thompson seedless" grapevines and Mikhael et al., (2010) on "Dessert Red" peach trees. They indicated that, $\mathrm{K}$ application enhanced leaf growth characteristics. On the other hand, the increment in leaf growth parameters as a result of foliar spray with Mg may be attributed to its role as the central atom of chlorophyll molecule, converts light energy into chemical energy and is essential for photosynthesis (Allison, et al., 2001). Also, Mostafa et al., (2007) and, Soliman, (2003), indicated that foliar spray of $\mathrm{Mg}$ improved growth parameters.

Concerning the effect of irrigation treatments data clearly showed that, leaf area has been reduced significantly with decreasing soil moisture content in both seasons in "Anna" apple trees. As for the specific leaf weight there were a significant differences between irrigation treatments under investigation, whereas the highest values of specific leaf weight were produced by irrigation the trees at $75 \%$ from the control $\left(\mathrm{I}_{2}\right)$, while the lowest values were 
recorded with trees irrigated at 50\% from the control $\left(I_{3}\right)$. The reduction in leaf area could be attributed to the great inhibition of cell enlargement under reducing cell turgidity (soliman,2003).In addition, Mpelascoka et al., (2001) indicated that the reduction in tree growth under water stress condition could be due to lower photosynthetic rate and stomatal conductance. The obtained results are in line with those of Nawar and Thanaa(1993) on Apricot seedlings, ElShereif (1998) on some Grape varieties and Mikhael et al., (2010) on "Dessert Red" peach. They found that leaf growth was significantly reduced under water stress.

The significant influence of the interaction between foliar application with $\mathrm{K}, \mathrm{Mg}$, and $(\mathrm{K}+\mathrm{Mg})$ and studied irrigation treatments on leaf area was recorded in "Anna" apple trees in the second season. $l_{1} \times(\mathrm{K}+\mathrm{Mg})$ treatment gave the highest value of area per leaf. Meanwhile, the least value belonged the $I_{3} x$ W treatment. Regarding to specific leaf weight, the interactions between nutrient sprays and tested irrigation treatments didn't exert any significant effect in both seasons.

\subsection{Water relations:}

Total water content and water deficit percentage in "Anna" apple leaves as affected by foliar spray with nutrient solution $(\mathrm{Mg}, \mathrm{K}$, and $\mathrm{K}+\mathrm{Mg})$ and irrigation treatments as well as their interaction are shown in Table ( 4 ).

Concerning the effect of foliar spray with $\mathrm{Mg}, \mathrm{K}$, and $(\mathrm{K}+\mathrm{Mg})$ it was observed that, $\mathrm{K}$ and $(\mathrm{K}+\mathrm{Mg})$ treatments significantly increased total water content and decreased water deficit percentage in leaves compared to $\mathrm{Mg}$ treatment or control (W). This results were true in both seasons. Potassium has greater role in the maintenance of water economy of plant by increasing relative water contents under water stress conditions. This is due to the increasing root length and more absorption of water from roots and then maintenance of water in leaf cells by closing the stomata. Also, Aslam et al., (2013) reported that, such kind of increase in relative water contents with potassium application might be recognized to increase cell turgor by osmotic adjustment. Similar findings were also reported by Umar and Moinuddin (2002). On the contrary, El-Sammak and Zayan (1988), Soliman (2003) and Vafaie et al., (2013) found that leaf moisture content was decreased by $\mathrm{Mg}$ fertilization, due to increasing dry matter percentage.

As for irrigation treatments effect, data indicate that, total water content was significantly decreased while water deficit percentage was increased in leaves of "Anna" apple trees by decreasing soil moisture content in the two seasons. Total water content of leaves increased as available water in the soil increased, consequently the water deficit percentage decreased. These results agree with those of El-Shereif (1998) on some Grape varieties, Abd El-Messeih (2000) on "Anna" apple trees, soliman (2003) on some deciduous fruit trees and Mikhael et al., (2010) on peach.

The interaction between foliar spray with studied nutrient solution and irrigation treatments recorded significant effect on total water content in leaves of "Anna" apple trees in the second season. As the trees were sprayed with $(\mathrm{K}+\mathrm{Mg})$ or $\mathrm{K}$ gave the highest value under control $\left(I_{1}\right)$, while the lowest values were produced when trees were unsprayed with nutrients (W) and irrigated at $50 \%$ from control $\left(I_{3}\right)$. With regard to water deficit percentage, the interaction between foliar spray with nutrient and irrigation treatments didn't exert any significant effect in the two season.

\section{1-3- Leaf chlorophyll reading:}

Leaf chlorophyll reading of "Anna" apple trees as affected by foliar spray with nutrient solution $(\mathrm{Mg}, \mathrm{K}$, and $\mathrm{K}+\mathrm{Mg}$ ) and irrigation treatments as well as their interactions are shown in Table (4).

Foliar spray with investigated elements $(\mathrm{Mg}, \mathrm{K}$ and $\mathrm{K}+\mathrm{Mg}$ ) revealed a significant 
increase in leaf chlorophyll compared to the unsprayed trees in the two growing seasons. Among the foliar spray treatments, the application of $\mathrm{K}+\mathrm{Mg}$ gave the highest leaf chlorophyll value followed by $\mathrm{Mg}$ treatment compared to $\mathrm{K}$. The favorable effect of the nutrients spray might be due to its role in chlorophyll synthesis. These results are in harmony with those reported by El-Sabrout and Kassem (2002) on orange and ElSeginy (2006) on "Canino" apricot, they found that the highest leaf chlorophyll reading was associated with high level of potassium fertilization. On the contrary, El-
Morshedy (1997) and Mikhael et al., (2010) on peach mentioned that the chlorophyll values were depressed as potassium dose increased. On the other hand, The enhancement effect of $\mathrm{Mg}$ on leaf total chlorophyll content may be attributed to the fact that $\mathrm{Mg}$ is an essential element for chlorophyll molecule structure that regulates photosynthesis (Spiegel - Roy and Goldschmidt, 2008). Also, the increase in the amount of $\mathrm{Mg}$ application leads to an increase in leaf total chlorophyll content and hence photosynthesis level was increased (Salama, et al., 2014).

Table (4). Effect of foliar spray with potassium and magnesium elements on leaf area, specific leaf weight, total water content, water deficit and chlorophyll content of Anna apple trees under water deficit condition during 2015 \& 2016 seasons.

\begin{tabular}{|c|c|c|c|c|c|c|c|c|c|c|c|c|}
\hline \multicolumn{3}{|c|}{ Treatments } & \multicolumn{2}{|c|}{$\begin{array}{l}\text { leaf area } \\
\left(\mathrm{cm}^{2}\right)\end{array}$} & \multicolumn{2}{|c|}{$\begin{array}{c}\text { specific leaf } \\
\text { weight } \\
\left(\mathrm{mg} / \mathrm{cm}^{2}\right)\end{array}$} & \multicolumn{2}{|c|}{$\begin{array}{l}\text { Total water } \\
\text { content (\%) }\end{array}$} & \multicolumn{2}{|c|}{$\begin{array}{l}\text { Water deficit } \\
(\%)\end{array}$} & \multicolumn{2}{|c|}{$\begin{array}{c}\text { chlorophyll } \\
\text { content } \\
\text { (SPAD) }\end{array}$} \\
\hline \multicolumn{2}{|c|}{$\begin{array}{l}\text { Foliar } \\
\text { application }\end{array}$} & Irrigation & 2015 & 2016 & 2015 & 2016 & 2015 & 2016 & 2015 & 2016 & 2015 & 2016 \\
\hline \multirow{3}{*}{\multicolumn{2}{|c|}{ W }} & $\mathrm{I}_{1}$ & 33.07 & 34.01 & 10.61 & 10.37 & 74.04 & 70.22 & 16.80 & 18.80 & 51.2 & 51.2 \\
\hline & & $\mathrm{I}_{2}$ & 32.47 & 33.08 & 11.72 & 10.15 & 70.62 & 68.76 & 20.50 & 22.50 & 51.0 & 50.4 \\
\hline & & $\mathrm{I}_{3}$ & 25.68 & 27.06 & 9.47 & 9.69 & 63.96 & 62.52 & 23.45 & 24.60 & 47.3 & 48.4 \\
\hline \multirow{3}{*}{\multicolumn{2}{|c|}{$\mathrm{Mg}$}} & $\mathrm{I}_{1}$ & 40.78 & 42.24 & 11.13 & 11.71 & 73.42 & 68.31 & 14.70 & 16.96 & 58.0 & 56.3 \\
\hline & & $\mathrm{I}_{2}$ & 37.08 & 35.40 & 10.99 & 12.79 & 70.03 & 66.80 & 19.30 & 19.45 & 57.8 & 55.0 \\
\hline & & $\mathrm{I}_{3}$ & 30.28 & 29.13 & 10.40 & 11.37 & 64.40 & 64.20 & 22.35 & 21.30 & 50.5 & 51.0 \\
\hline \multirow{3}{*}{\multicolumn{2}{|c|}{$\mathrm{K}$}} & $l_{1}$ & 43.70 & 43.10 & 10.79 & 11.87 & 75.49 & 71.98 & 14.05 & 14.60 & 56.6 & 54.2 \\
\hline & & $\mathrm{I}_{2}$ & 39.63 & 40.02 & 11.22 & 12.07 & 71.72 & 70.13 & 17.20 & 19.10 & 54.2 & 53.0 \\
\hline & & $\mathrm{I}_{3}$ & 30.22 & 30.41 & 10.78 & 11.01 & 66.39 & 66.33 & 20.30 & 20.68 & 48.3 & 49.6 \\
\hline \multirow{3}{*}{\multicolumn{2}{|c|}{$\mathrm{K}+\mathrm{Mg}$}} & $\mathrm{l}_{1}$ & 44.00 & 45.35 & 11.30 & 12.22 & 75.85 & 71.85 & 13.95 & 14.30 & 59.3 & 58.3 \\
\hline & & $\mathrm{I}_{2}$ & 42.19 & 42.27 & 11.27 & 11.74 & 73.48 & 68.76 & 17.10 & 19.09 & 58.8 & 58.3 \\
\hline & & $\mathrm{I}_{3}$ & 31.49 & 31.75 & 11.07 & 11.62 & 66.88 & 64.64 & 20.07 & 20.48 & 53.1 & 52.6 \\
\hline \multicolumn{13}{|c|}{ Average foliar application } \\
\hline \multicolumn{3}{|c|}{ W } & 30.41 & 31.38 & 10.60 & 10.07 & 69.54 & 67.17 & 20.25 & 21.97 & 49.83 & 50.00 \\
\hline \multicolumn{3}{|c|}{$\mathrm{Mg}$} & 36.05 & 35.59 & 10.84 & 11.96 & 69.28 & 66.44 & 18.78 & 19.24 & 55.43 & 54.10 \\
\hline \multicolumn{3}{|c|}{$\mathrm{K}$} & 37.85 & 37.84 & 10.93 & 11.65 & 71.20 & 69.48 & 17.18 & 18.13 & 53.03 & 52.27 \\
\hline \multicolumn{3}{|c|}{$\mathrm{K}+\mathrm{Mg}$} & 39.23 & 39.79 & 11.21 & 11.86 & 72.07 & 68.42 & 17.04 & 17.96 & 57.07 & 56.40 \\
\hline \multicolumn{13}{|c|}{ Average irrigation } \\
\hline \multicolumn{3}{|c|}{$I_{1}$} & 40.39 & 41.17 & 10.96 & 11.54 & 74.70 & 70.59 & 14.87 & 16.16 & 56.27 & 55.00 \\
\hline \multicolumn{3}{|c|}{$\mathrm{I}_{2}$} & 37.84 & 37.69 & 11.30 & 11.69 & 71.46 & 68.61 & 18.52 & 20.03 & 55.45 & 54.17 \\
\hline \multicolumn{3}{|c|}{$\mathrm{I}_{3}$} & 29.42 & 29.59 & 10.34 & 10.92 & 65.41 & 64.42 & 21.54 & 21.76 & 49.80 & 50.40 \\
\hline \multirow{3}{*}{$\begin{array}{l}\text { LSD } \\
(5 \%)\end{array}$} & \multicolumn{2}{|c|}{ Foliar Appl. } & 1.68 & 1.93 & 0.55 & 0.74 & 1.19 & 1.16 & 1.10 & 0.98 & 1.97 & 1.36 \\
\hline & \multicolumn{2}{|c|}{ irrigation } & 1.91 & 0.77 & 0.51 & 0.42 & 0.77 & 0.74 & 0.68 & 0.76 & 1.68 & 0.87 \\
\hline & \multicolumn{2}{|c|}{ Interaction } & NS & 1.55 & NS & NS & NS & 1.48 & NS & NS & NS & NS \\
\hline
\end{tabular}

$\mathrm{I}_{1}, \mathrm{I}_{2}$ and $\mathrm{I}_{3}: 100 \%$ (control), $75 \%$ (control) and 50\%(control) ; W: tap water, Mg, K: magnesium ,potassium application 
With regard to irrigation treatments and their effects on leaf chlorophyll content, the results showed that there were significant differences among treatments in the two seasons. $I_{1}$ treatment (control) gave the highest values of leaf chlorophyll while irrigated trees at $50 \%$ from control $\left(\mathrm{I}_{3}\right)$ recorded the lowest value in the first and second seasons. The reduction in leaf chlorophyll due to the shortage of water supply could be explained by a suppression of nutrients absorption specially $\mathrm{N}$ and $\mathrm{Mg}$ elements via the root and by plastid breakdown under water stress conditions. The obtained results agree with those of El-
Shereif (1998) on some Grape varieties , Soliman (2003) on some deciduous fruit trees.

The interaction between foliar application of studied nutrients and irrigation treatments on leaf chlorophyll didn't record any significant influence in the two seasons.

\section{Leaf- NPK and Mg contents:}

Data pertaining to leaf macronutrients of "Anna" apple trees as affected by foliar application of nutrient $(\mathrm{K}, \mathrm{Mg}$, and $\mathrm{K}+\mathrm{Mg})$ and irrigation treatments as well as their interactions are presented in Table (5).

Table (5). Effect of foliar spray with potassium and magnesium elements on leaf macronutrients of Anna apple trees under water deficit condition during 2015 \& 2016 seasons.

\begin{tabular}{|c|c|c|c|c|c|c|c|c|c|c|}
\hline \multicolumn{3}{|c|}{ Treatments } & \multicolumn{2}{|c|}{$\begin{array}{c}\text { Leaf-N } \\
\text { content }(\%)\end{array}$} & \multicolumn{2}{|c|}{$\begin{array}{c}\text { Leaf-P } \\
\text { content }(\%)\end{array}$} & \multicolumn{2}{|c|}{$\begin{array}{c}\text { Leaf-K } \\
\text { content }(\%)\end{array}$} & \multicolumn{2}{|c|}{$\begin{array}{c}\text { Leaf-Mg } \\
\text { content }(\%)\end{array}$} \\
\hline Folia & application & Irrigation & 2015 & 2016 & 2015 & 2016 & 2015 & 2016 & 2015 & 2016 \\
\hline \multirow{3}{*}{\multicolumn{2}{|c|}{ W }} & $I_{1}$ & 2.40 & 2.33 & 0.25 & 0.22 & 1.41 & 1.43 & 0.35 & 0.35 \\
\hline & & $\mathrm{I}_{2}$ & 2.11 & 2.20 & 0.21 & 0.22 & 1.37 & 1.30 & 0.31 & 0.29 \\
\hline & & $I_{3}$ & 1.93 & 1.95 & 0.14 & 0.17 & 1.24 & 1.23 & 0.26 & 0.27 \\
\hline \multirow{3}{*}{\multicolumn{2}{|c|}{$\mathrm{Mg}$}} & $I_{1}$ & 2.47 & 2.53 & 0.29 & 0.30 & 1.48 & 1.40 & 0.42 & 0.43 \\
\hline & & $\mathrm{I}_{2}$ & 2.33 & 2.40 & 0.25 & 0.27 & 1.45 & 1.39 & 0.38 & 0.38 \\
\hline & & $\mathrm{I}_{3}$ & 2.00 & 2.18 & 0.21 & 0.22 & 1.32 & 1.23 & 0.33 & 0.35 \\
\hline \multirow{3}{*}{\multicolumn{2}{|c|}{$\mathrm{K}$}} & $I_{1}$ & 2.47 & 2.59 & 0.30 & 0.32 & 1.77 & 1.69 & 0.39 & 0.35 \\
\hline & & $\mathrm{I}_{2}$ & 2.42 & 2.46 & 0.28 & 0.30 & 1.75 & 1.75 & 0.36 & 0.33 \\
\hline & & $\mathrm{I}_{3}$ & 2.05 & 2.23 & 0.20 & 0.22 & 1.38 & 1.40 & 0.29 & 0.30 \\
\hline \multirow{3}{*}{\multicolumn{2}{|c|}{$\mathrm{K}+\mathrm{Mg}$}} & $\mathrm{I}_{1}$ & 2.50 & 2.63 & 0.32 & 0.34 & 1.80 & 1.79 & 0.47 & 0.47 \\
\hline & & $\mathrm{I}_{2}$ & 2.46 & 2.51 & 0.30 & 0.32 & 1.79 & 1.80 & 0.42 & 0.43 \\
\hline & & $I_{3}$ & 2.16 & 2.26 & 0.24 & 0.23 & 1.40 & 1.43 & 0.34 & 0.36 \\
\hline \multicolumn{11}{|c|}{ Average foliar application } \\
\hline \multicolumn{3}{|c|}{ W } & 2.15 & 2.16 & 0.20 & 0.20 & 1.34 & 1.32 & 0.31 & 0.30 \\
\hline \multicolumn{3}{|c|}{$\mathrm{Mg}$} & 2.27 & 2.37 & 0.25 & 0.26 & 1.42 & 1.34 & 0.37 & 0.39 \\
\hline \multicolumn{3}{|c|}{ K } & 2.31 & 2.43 & 0.26 & 0.28 & 1.63 & 1.61 & 0.35 & 0.33 \\
\hline \multicolumn{3}{|c|}{$\mathrm{K}+\mathrm{Mg}$} & 2.37 & 2.47 & 0.29 & 0.30 & 1.66 & 1.67 & 0.41 & 0.42 \\
\hline \multicolumn{11}{|c|}{ Average irrigation } \\
\hline \multicolumn{3}{|c|}{$I_{1}$} & 2.46 & 2.52 & 0.29 & 0.29 & 1.61 & 1.58 & 0.41 & 0.40 \\
\hline \multicolumn{3}{|c|}{$\mathrm{I}_{2}$} & 2.33 & 2.39 & 0.26 & 0.28 & 1.59 & 1.56 & 0.37 & 0.36 \\
\hline \multicolumn{3}{|c|}{$I_{3}$} & 2.03 & 2.15 & 0.20 & 0.21 & 1.33 & 1.32 & 0.31 & 0.32 \\
\hline \multirow{3}{*}{$\begin{array}{l}\text { LSD } \\
(5 \%)\end{array}$} & \multicolumn{2}{|c|}{ Foliar application } & 0.10 & 0.04 & 0.02 & 0.02 & 0.03 & 0.05 & 0.01 & 0.02 \\
\hline & \multicolumn{2}{|c|}{ irrigation } & 0.05 & 0.06 & 0.02 & 0.01 & 0.02 & 0.02 & 0.02 & 0.02 \\
\hline & \multicolumn{2}{|c|}{ Interaction } & 0.09 & 0.11 & NS & 0.02 & 0.04 & 0.05 & NS & NS \\
\hline
\end{tabular}

$\mathrm{I}_{1}, \mathrm{I}_{2}$ and $\mathrm{I}_{3}: 100 \%$ (control), $75 \%$ (control) and $50 \%$ (control); W: tap water, $\mathrm{Mg}, \mathrm{K}$ : magnesium , potassium application 
Concerning the effect of nutrient sprays on "Anna" apple trees, it was found that solution spray of nutrient significantly increased leaf-N,P,K and $\mathrm{Mg}$ contents in both seasons. The highest values were obtained with $(\mathrm{K}+\mathrm{Mg})$ treatment, likewise the lowest values were produced when no nutrient sprays were applied. With respect to the individual application of $\mathrm{Mg}$ and $\mathrm{K}$, the application of $\mathrm{K}$ was superior to $\mathrm{Mg}$ application on leaf- $\mathrm{N}, \mathrm{P}$ and $\mathrm{K}$ contents, however the application of $\mathrm{Mg}$ was superior to $\mathrm{K}$ on leaf-Mg content. The obtained results regarding the effect of magnesium fertilizer on leaf mineral content go in line with the finding of Ahmed and Morsy (2001) on Canino apricot and Fawzi et al. (2010) on Le Conte pear;. They noticed that magnesium fertilizer improved leaf mineral content of the aforementioned fruit species. Also spraying potassium was highly effective in improving, nutritional status of "Anna" apple trees (Mosa, et al., 2015). In addition, El-sherif et al,. 2008 reported that, spraying "Golden Japanese" plum by four potassium fertilizer sources at bud burst, after fruit set and one month after fruit set increased significantly leaf macro-elements content.

As for irrigation treatments data showed that, irrigation treatments had significant effect on leaf-N,P,K and $\mathrm{Mg}$ contents of "Anna" apple trees in both seasons, whereas the deficit of irrigation water up to $50 \%$ of control decreased leaf- $\mathrm{N}, \mathrm{P}, \mathrm{K}$ and $\mathrm{Mg}$ contents to lowest values. On the other hand, the highest values were recorded at control (unstressed plants). These results could be led to a conclusion that nutrients uptake was retarded under water stress conditions, where the root failed to absorb the accumulative valuable nutrient elements (Mikhael, et al, 2010). Moreover, depletion of soil moisture level caused a reduction in leaf mineral contents due to reduced active rooting as an indirect influence (Abd ElMesseih and El-Gendy, 2004). The results are in partial agreement with those found by many investigators such as Hussein (1998) on 'Anna" apple trees, Fathi et al. (1999) on some deciduous fruit rootstocks, Abd EL Messeih (2000) on apple and Mikhael (2007) on "Anna" apple trees. They concluded that, leaf mineral content and significantly increased as a result of optimum irrigation rate applied.

Leaf-N,P and K contents of "Anna" apple trees significantly responded to interaction between foliar application with $\mathrm{K}, \mathrm{Mg}$ and $\mathrm{K}+\mathrm{Mg}$ and irrigation treatments in both seasons, while leaf-Mg content didn't exert any significant affect in both seasons. The highest values of leaf-N,P and $K$ were obtained by $\mathrm{I}_{1}$ treatment (control) when the plants were sprayed with $\mathrm{K}$ and $\mathrm{Mg}$, while the lowest values was produced by $\mathrm{I}_{3}$ treatment $(50 \%$ from control) when plants received no foliar applications of the nutrient solution (W).

\section{Yield:}

Fruit set, yield and fruit weight of "Anna" apple trees as affected by foliar spray with nutrient solution ( $\mathrm{Mg}, \mathrm{K}$ and $\mathrm{K}+\mathrm{Mg}$ ) and irrigation treatments as well as their interaction are shown in Table (6).

The obtained results show that all sprays significantly increased fruit set, yield per tree $(\mathrm{kg})$ and total yield $(\mathrm{kg} / \mathrm{fed})$ in the two growing seasons. The effect of $(\mathrm{K}+\mathrm{Mg})$ treatment has exceeded the effects of the other two treatments, while the effect of $\mathrm{Mg}$ has logged behind the effect of $\mathrm{K}$. With regard to fruit weight, in the first season $(\mathrm{K}+\mathrm{Mg})$ treatment significantly increased fruit weight over the other two treatments and control, while in the second one all foliar spray treatments recorded a significant increase in fruit weight compared to the control. Similar trend was found by Kilany and Kilany (1991) on apple trees, El-Seginy (2006) on "canino" apricot trees and Mikhael et al., (2010) on peach trees, who reported that potassium fertilization treatments produced a significant increase in yield by the stimulation effect of potassium in increasing number of fruit per tree and 
average fruit weight. As for magnesium effect, the results were supported by those obtained with Fawzi et al., (2010) on Le Conte pear trees, who stated that yield expressed in weight and number of fruit/tree was positively affected by spraying magnesium sulphate.

Table (6). Effect of foliar spray with potassium and magnesium elements on fruit set, yield, water use efficiency (WUE) and fruit weight of Anna apple trees under water deficit condition during 2015 \& 2016 seasons.

\begin{tabular}{|c|c|c|c|c|c|c|c|c|c|c|c|c|}
\hline \multicolumn{3}{|c|}{ Treatments } & \multicolumn{2}{|c|}{$\begin{array}{c}\text { Fruit Set } \\
(\%)\end{array}$} & \multicolumn{2}{|c|}{$\begin{array}{c}\text { Yield } \\
\text { (Kg/tree) }\end{array}$} & \multicolumn{2}{|c|}{$\begin{array}{c}\text { Yield } \\
\text { (ton/fed) }\end{array}$} & \multicolumn{2}{|c|}{$\begin{array}{l}\text { Water use } \\
\text { efficiency } \\
\left(\mathrm{kg} / \mathrm{m}^{3}\right)\end{array}$} & \multicolumn{2}{|c|}{$\begin{array}{l}\text { Fruit weight } \\
\quad(\mathrm{gm}),\end{array}$} \\
\hline \multicolumn{2}{|c|}{$\begin{array}{l}\text { Foliar } \\
\text { application }\end{array}$} & Irrigation & 2015 & 2016 & 2015 & 2016 & 2015 & 2016 & 2015 & 2016 & 2015 & 2016 \\
\hline \multirow{3}{*}{\multicolumn{2}{|c|}{ W }} & $I_{1}$ & 12.38 & 13.72 & 25.02 & 23.38 & 4.203 & 3.928 & 1.60 & 1.49 & 161 & 156 \\
\hline & & $\mathrm{I}_{2}$ & 10.10 & 10.08 & 20.41 & 17.17 & 3.429 & 2.885 & 1.73 & 1.47 & 155 & 131 \\
\hline & & $\mathrm{I}_{3}$ & 7.94 & 8.78 & 16.04 & 14.96 & 2.688 & 2.514 & 2.05 & 1.91 & 123 & 128 \\
\hline \multirow{3}{*}{\multicolumn{2}{|c|}{$\mathrm{Mg}$}} & $I_{1}$ & 15.12 & 18.35 & 30.56 & 31.27 & 5.134 & 5.252 & 1.96 & 2.00 & 182 & 184 \\
\hline & & $\mathrm{I}_{2}$ & 11.93 & 13.79 & 20.07 & 23.50 & 3.372 & 3.948 & 1.72 & 2.01 & 140 & 148 \\
\hline & & $I_{3}$ & 9.95 & 10.96 & 18.08 & 18.67 & 3.038 & 3.137 & 2.31 & 2.39 & 134 & 133 \\
\hline \multirow{3}{*}{\multicolumn{2}{|c|}{$\mathrm{K}$}} & $\mathrm{I}_{1}$ & 15.87 & 18.95 & 32.08 & 32.29 & 5.390 & 5.425 & 2.05 & 2.07 & 183 & 181 \\
\hline & & $\mathrm{I}_{2}$ & 12.38 & 15.02 & 25.03 & 25.60 & 4.185 & 4.301 & 2.14 & 2.19 & 145 & 151 \\
\hline & & $\mathrm{I}_{3}$ & 10.50 & 11.83 & 21.23 & 20.16 & 3.567 & 3.387 & 2.72 & 2.58 & 152 & 133 \\
\hline \multirow{3}{*}{\multicolumn{2}{|c|}{$\mathrm{K}+\mathrm{Mg}$}} & $l_{1}$ & 17.56 & 20.48 & 35.50 & 34.90 & 5.964 & 5.863 & 2.27 & 2.23 & 195 & 188 \\
\hline & & $\mathrm{I}_{2}$ & 14.89 & 17.40 & 30.10 & 29.65 & 5.399 & 4.981 & 2.58 & 2.54 & 164 & 160 \\
\hline & & $I_{3}$ & 11.07 & 12.36 & 23.05 & 21.06 & 3.872 & 3.538 & 2.95 & 2.70 & 154 & 131 \\
\hline \multicolumn{13}{|c|}{ Average foliar application } \\
\hline \multicolumn{3}{|c|}{ W } & 10.14 & 10.86 & 20.49 & 18.50 & 3.440 & 3.109 & 1.80 & 1.63 & 152 & 138 \\
\hline \multicolumn{3}{|c|}{$\mathrm{Mg}$} & 12.33 & 14.37 & 22.90 & 24.48 & 3.848 & 4.112 & 2.00 & 2.14 & 146 & 155 \\
\hline \multicolumn{3}{|c|}{ K } & 12.92 & 15.27 & 26.11 & 26.02 & 4.387 & 4.371 & 2.31 & 2.28 & 160 & 155 \\
\hline \multicolumn{3}{|c|}{$\mathrm{K}+\mathrm{Mg}$} & 14.51 & 16.75 & 29.55 & 28.54 & 5.078 & 4.794 & 2.60 & 2.49 & 171 & 159 \\
\hline \multicolumn{13}{|c|}{ Average irrigation } \\
\hline \multicolumn{3}{|c|}{$\mathrm{l}_{1}$} & 15.23 & 17.87 & 30.79 & 30.46 & 5.173 & 5.117 & 1.97 & 1.95 & 180 & 177 \\
\hline \multicolumn{3}{|c|}{$\mathrm{I}_{2}$} & 12.32 & 14.07 & 23.90 & 23.98 & 4.101 & 4.029 & 2.04 & 2.05 & 147 & 147 \\
\hline \multicolumn{3}{|c|}{$\mathrm{I}_{3}$} & 9.86 & 10.98 & 19.60 & 18.71 & 3.291 & 3.144 & 2.51 & 2.40 & 145 & 131 \\
\hline \multirow{3}{*}{$\begin{array}{l}\text { LSD } \\
(5 \%)\end{array}$} & \multicolumn{2}{|c|}{ Foliar Appl. } & 0.72 & 0.87 & 1.22 & 1.02 & 0.222 & 0.171 & 0.19 & 0.13 & 9.63 & 6.97 \\
\hline & \multicolumn{2}{|c|}{ irrigation } & 0.86 & 0.89 & 0.90 & 1.27 & 0.188 & 0.213 & 0.19 & 0.25 & 7.43 & 9.21 \\
\hline & \multicolumn{2}{|c|}{ Interaction } & NS & NS & 1.79 & 2.53 & 0.376 & 0.425 & 0.38 & NS & 14.86 & NS \\
\hline
\end{tabular}

$\mathrm{I}_{1}, \mathrm{I}_{2}$ and $\mathrm{I}_{3}: 100 \%$ (control), $75 \%$ (control) and $50 \%$ (control); $\mathrm{W}$ : tap water, $\mathrm{Mg}, \mathrm{K}$ : magnesium , potassium application 
Concerning the effect of irrigation treatments, data presented in Table (6) showed that the maximum fruit set, yield(kg/tree), total yield (ton/fed)and fruit weight of "Anna" apple trees were gained by treatment $I_{1}$ in the two growing seasons. However, the lowest fruit set percentage, yield and fruit weight were recorded from treatment $I_{3}$ which received the least water amount in the first and second seasons. These results may be attributed to the greater amount of synthesized metabolites which can be considered as a final result of improving all physiological processes including nutrient uptake (Khalil, 1991). These results are in full agreement with reported by Ali et al., (1998), and Khalil et al., (2000), who stated that adequate water supply for apple trees in an important factor for maximizing its production. Also, these results agreement with reported by $\mathrm{El}$ Seginy (2006) on "canino" apricot trees and Mikhael et al., (2010) on peach trees.

The interaction effect on yield $(\mathrm{kg} / \mathrm{tree})$ and total yield (ton/fed) was significant in the two growing seasons, when the highest yield was obtained by combination between $(\mathrm{K}+\mathrm{Mg})$ and $\mathrm{I}_{1}$ treatments, while the lowest yield was recorded by combination between $\mathrm{W} \times \mathrm{I}_{3}$. As for fruit weight, the interaction was recorded in the first season, when the highest value of fruit weight was obtained with $(\mathrm{K}+\mathrm{Mg}) \times \mathrm{I}_{1}$, while the lowest value was recorded by $\mathrm{W} \mathrm{I}_{3}$ treatment.

\section{Water use efficiency:}

Water use efficiency ( WUE ) used in this study to evaluate the effectiveness of irrigation and foliar spray with $\mathrm{Mg}, \mathrm{K}$ and $\mathrm{K}+\mathrm{Mg}$ and their interaction for maximum utilization of water supplies in "Anna" apple trees. It is clear from data in Table (6) that, the highest significant values of WUE were obtained from trees sprayed with $(\mathrm{K}+\mathrm{Mg})$ in both seasons followed in descending order by those sprayed with $\mathrm{K}$ and $\mathrm{Mg}$, respectively. Similar results were obtained Mikhael et al., (2010) and Jaroszewska,
(2015), who found that water use efficiency (WUE) increased by fertilization treatments.

WUE significantly increased under water shortage conditions $\left(I_{3}\right)$ and decreased when water was more available $\left(l_{1}\right)$. Which may indicate that the plants make better use of water under conditions of scarcity water than under optimal moisture (Medrano et al. 2009, Yin et al. 2012 and Jaroszewska, 2015 ). The transpiration intensity is closely correlated to the water use effectiveness in the plants during their vegetation period (Jaroszewska , 2015).

The significant influence of the interaction between foliar spray with tested nutrient and irrigation treatments on water use efficiency (WUE) was observed in "Anna" apple trees in the first season only. The highest values was estimated for deficit irrigation rate with $\mathrm{K}+\mathrm{Mg}$ foliar application, while the lowest WUE recorded by unsprayed trees (W) under control $\left(I_{1}\right)$.

\section{Fruit firmness:}

Effect of the nutrient solution ( $\mathrm{Mg}, \mathrm{K}$, and $\mathrm{K}+\mathrm{Mg}$ ) and irrigation treatments as well as their interaction on fruit firmness of "Anna" apple trees are presented in Table (7).

The effect of nutrient solution $(\mathrm{Mg}, \mathrm{K}$, and $\mathrm{K}+\mathrm{Mg}$ ) on firmness "Anna" apple fruits showed a significant variation in the two seasons, whereas the trees sprayed with $\mathrm{K}+\mathrm{Mg}$ gave the highest firmness followed by $\mathrm{K}$ treatment, while the least significant value was detected in unsprayed trees $(W)$ in both seasons. Similar trend was found by ElSeginy (2006) on "Canino" apricot, Abd ElFatah et al., (2008) on "Costata" persimmon and Mosa et al., (2015) on "Anna" apple Who reported that potassium sulphate increased fruit firmness. The role of $\mathrm{Mg}$ could be also explained in increasing fruit firmness was similar to the role of $\mathrm{Ca}$ in increasing cell membrane integrity by binding to the polar head groups of phospholipids (Frag and Nagy, 2012). 
Table (7). Effect of foliar spray with potassium and magnesium elements on fruit firmness, total soluble solids, acidity and anthocyanin of Anna apple trees under water deficit condition during 2015 \& 2016 seasons.

\begin{tabular}{|c|c|c|c|c|c|c|c|c|c|c|}
\hline & Treatme & & $\begin{array}{l}\text { fruit fir } \\
\qquad(\mathrm{I} \mathrm{b} / \mathrm{i}\end{array}$ & $\begin{array}{l}\text { nness } \\
\text { nch }^{2} \text { ) }\end{array}$ & $\begin{array}{r}\text { Total } \\
\text { solic }\end{array}$ & $\begin{array}{l}\text { oluble } \\
(\%)\end{array}$ & & & $\begin{array}{l}\text { Antho } \\
\text { (mg) } \\
\text { fresh } \\
\text { pe }\end{array}$ & $\begin{array}{l}\text { cyanin } \\
00 \mathrm{~g} \\
\text { veight } \\
\text { el) }\end{array}$ \\
\hline Foliar & application & Irrigation & 2015 & 2016 & 2015 & 2016 & 2015 & 2016 & 2015 & 2016 \\
\hline & W & $\mathrm{I}_{1}$ & 9.05 & 8.81 & 10.94 & 10.66 & 0.51 & 0.49 & 21.24 & 21.33 \\
\hline & & $\mathrm{I}_{2}$ & 10.15 & 9.36 & 11.25 & 11.01 & 0.54 & 0.50 & 21.93 & 22.06 \\
\hline & & $\mathrm{I}_{3}$ & 10.43 & 10.48 & 11.03 & 11.11 & 0.55 & 0.52 & 22.09 & 22.49 \\
\hline & $\mathrm{Mg}$ & $I_{1}$ & 9.33 & 8.90 & 11.01 & 10.60 & 0.47 & 0.48 & 21.69 & 21.56 \\
\hline & & $\mathrm{I}_{2}$ & 10.52 & 9.53 & 11.57 & 11.57 & 0.51 & 0.51 & 22.33 & 22.63 \\
\hline & & $\mathrm{I}_{3}$ & 10.58 & 10.64 & 11.32 & 11.33 & 0.51 & 0.52 & 22.73 & 22.86 \\
\hline & $\mathrm{K}$ & $I_{1}$ & 10.10 & 9.75 & 11.14 & 11.35 & 0.50 & 0.45 & 24.43 & 25.27 \\
\hline & & $\mathrm{I}_{2}$ & 10.94 & 10.97 & 11.95 & 12.14 & 0.52 & 0.51 & 27.68 & 27.86 \\
\hline & & $I_{3}$ & 11.21 & 11.03 & 11.96 & 11.97 & 0.52 & 0.51 & 28.31 & 28.40 \\
\hline & $\mathrm{K}+\mathrm{Mg}$ & $I_{1}$ & 10.49 & 9.75 & 11.15 & 11.78 & 0.52 & 0.48 & 25.27 & 25.43 \\
\hline & & $\mathrm{I}_{2}$ & 10.81 & 11.01 & 12.04 & 12.55 & 0.53 & 0.51 & 29.80 & 30.10 \\
\hline & & $I_{3}$ & 11.63 & 11.54 & 12.81 & 12.50 & 0.54 & 0.51 & 30.18 & 30.00 \\
\hline & & & Ave & age fol & ar appli & tion & & & & \\
\hline & W & & 9.88 & 9.55 & 11.07 & 10.93 & 0.53 & 0.50 & 21.75 & 22.07 \\
\hline & $\mathrm{Mg}$ & & 10.14 & 9.69 & 11.30 & 11.17 & 0.50 & 0.50 & 22.25 & 22.35 \\
\hline & K & & 10.75 & 10.52 & 11.68 & 11.81 & 0.51 & 0.49 & 26.81 & 27.18 \\
\hline & $\mathrm{K}+\mathrm{Mg}$ & & 10.98 & 10.77 & 12.00 & 12.28 & 0.53 & 0.50 & 28.41 & 28.51 \\
\hline & & & & Average & irrigatic & & & & & \\
\hline & $\mathrm{I}_{1}$ & & 9.74 & 9.30 & 11.06 & 11.10 & 0.50 & 0.47 & 23.16 & 23.40 \\
\hline & $\mathrm{I}_{2}$ & & 10.60 & 10.17 & 11.70 & 11.82 & 0.52 & 0.51 & 25.43 & 25.66 \\
\hline & $\mathrm{I}_{3}$ & & 10.96 & 10.92 & 11.78 & 11.72 & 0.53 & 0.51 & 25.83 & 26.02 \\
\hline LSD & Foliar ar & lication & 0.17 & 0.30 & 0.42 & 0.64 & NS & NS & 0.56 & 1.38 \\
\hline$(5 \%)$ & irrig & tion & 0.21 & 0.12 & 0.31 & 0.40 & NS & 0.02 & 0.50 & 0.96 \\
\hline & Inter & tion & NS & 0.24 & 0.62 & NS & 0.05 & NS & 1.01 & NS \\
\hline
\end{tabular}

$\mathrm{I}_{1}, \mathrm{I}_{2}$ and $\mathrm{I}_{3}: 100 \%$ (control), $75 \%$ (control) and 50\%(control); W: tap water, $\mathrm{Mg}, \mathrm{K}$ : magnesium ,potassium application 
As for the effect of irrigation treatments, the results clearly showed that fruit firmness markedly increased with decreasing water applied rates in both seasons. These findings were more pronounced with water irrigation at $50 \%$ of control $\left(\mathrm{I}_{3}\right)$. Such results may prove that the amount of applied water affects firmness. Such results were obtained by Ali et al., (1998), Abd El-Messeih (2000)and Khalil et al., (2000) on apple, ElSeginy (2006) on "Canino" apricot and Mikhael et al., (2010) on peach, who concluded that fruits produced under dry conditions were higher in the firmness value.

The significant effect of the interaction between foliar spray with $\mathrm{Mg}, \mathrm{K}$ and $\mathrm{K}+\mathrm{Mg}$ and irrigation treatments on fruit firmness of "Anna" apple trees was recorded in the second season. The highest fruit firmness was produced by $\mathrm{K}+\mathrm{Mg}$ treatment with water irrigation at $50 \%$ of control $\left(I_{3}\right)$, while unsprayed trees under control $\left(I_{1}\right)$ gave the lowest firmness value.

\section{Total soluble solids, acidity and anthocyanin content:}

The effect of foliar spray with nutrient solution $(\mathrm{Mg}, \mathrm{K}$, and $\mathrm{K}+\mathrm{Mg}$ ) and irrigation treatments and their interactions on total soluble solids, acidity and anthocyanin of "Anna" apple fruits in the two growing seasons are presented in Table (7).

Referring to the effect of foliar spray with tested nutrients, data indicated that total soluble solids and anthocyanin content were increased as a result of foliar spray with all nutrients under investigation, whereas $\mathrm{K}+\mathrm{Mg}$ treatment recorded a significant increase of total soluble solids percentage and anthocyanin value followed by $\mathrm{K}$ treatment, while the unsprayed trees gave the lowest total soluble solids percentage and anthocyanin value in the first and second seasons. As for fruit juice acidity, the results didn't show a significant differences in the two growing seasons. These results are in line with Kassem and El-Seginy (2002), ElSabrout and Kassem (2002), El-Seginy
(2006) and Mikhael et al., (2010) working on several fruit crops, they reported that, TSS $\%$, acidity $\%$ and anthocyanin value were positively related to potassium applied. They added that the lower hydrogen ion concentration with the concomitant positive correlation between potassium supply and total organic acids as potassium was increased. The obtained results of magnesium fertilizer regarding their positive effect on fruit physical and chemical properties are harmony with the finding of Ahmed and Morsy (2001) on Canino apricot; El-Seginy et al. (2003) on Anna apple; and Fawzi et al. (2010) on Le Conte pear. They mentioned that magnesium fertilizer improved fruit physical and chemical properties of the aforementioned fruit species.

Concerning the effect of irrigation treatment, data showed that total soluble solids percentage and anthocyanin value were significantly increased in the $I_{3}$ treatment followed by $I_{2}$ compared to $I_{1}$ in both season, the difference between $I_{3}$ and $\mathrm{I}_{2}$ treatments was not enough to be significant. On the contrary the acidity\% significantly increased with $I_{3}$ treatment followed by $I_{2}$ with no significant difference between them compared to $I_{1}$ in the second season, while in the first one the variation between treatments were not enough to be significant. These results indicated that fruit quality of "Anna" apple trees was to better by using a lot of water supply. These results agreed with those reported by Khlil et al., (2000), Mohamed (2003), El-Seginy (2006) and Mikhael et al., (2010) on several fruit crops.

As for the interaction effect between foliar spray with investigation nutrients and varying irrigation levels on total soluble solids $\%$, acidity $\%$ and anthocyanin value a significant differences were observed in the first season, whereas the highest percentage of total soluble solids, acidity and anthocyanin value were belonged to the combination between $\mathrm{K}+\mathrm{Mg}$ and $\mathrm{I}_{3}$ 
treatments, while the lowest values were recorded by unsprayed trees under control $\left(I_{1}\right)$.

\section{REFERENCES}

A.O.A.C., (Association of Official Agricultural Chemists) (1981). Official Method of Analysis. $11 \mathrm{Ed}$. Published by the A.O.th A.C., P.O. Box: 540, Washington. D.C., USA.

Abd El- Messeih, W. M. (2000). Response of "Anna" apple trees to different irrigation treatments combined with three nitrogen levels for scheduling irrigation and saving waterin new reclaimed soils. Ph. D. Thesis, Fac. Agric., Alex. Univ., Egypt.

Abd El-Messeih, W. M. and R. W. El-Gendy (2004). Effect of different trickle irrigation levels based on soil matric potential on 2leaf chemical composition and active rooting depth of "Canino" apricot trees planted on sandy soils. Alex. Sci. Exch., 25 (3): 481-495.

Abdel-Fattah, D.M., S.A. Mohamed and O.M. Ismail (2008). Effect of biostimulants, Etherl, boron and potassium nutrient on fruit quality of Costata persimmon. Aust. J. of Basic and Applied Sci., 2(4): 1432- 1437.

Abou Aziz, A.B., M.F. Mostafa, N.R. Samara and A.M. El-Tanahy (2000). Nutritional studies on banana plants. J. Agric. Sci. Mansoura Univ., 25(1): 433-439.

Ahmed, F.F. and M.H. Morsy (2001). Response of "Canino" apricot trees grown in the new reclaimed land to application of some nutrients and ascorbic acid. The fifth Arabian Hort. Conf. Ismailia, Egypt, pp: 27-34.

Ali, M.A., M.M. Mohmoud and A.Y. Sablia (1998). Effect of soil moisture stress on apple trees.Egypt J. Agric.(4): 1565-1583.

Allison, M. F., J. H. Fower and E. J. Allen (2001). Factors affecting the magnesium nutritionof potatoes (Solanum tuberosum L.). J. Agric. Sci. Cambridge., 137:397409.

Aslam, M., M. S. Zamir and I. Afzal (2013). Morphological and physiological response of maize hybrids to potassium application under drought stress. J. Agric. Res., 51(4)

Atkinson, C.J., M. Policarpo, A.D. Webster and G. Kingswell (2000). Drought tolerance of clonal Malus determined from measurements of stomatal conductance and leaf water potential. Tree Physiol. 20(8): 557-563.

Barrs, H. D. (1968). Determination of water deficit in plant tissues .In water deficit and plant growth (Kozlowski, T.T.,ed) 1:236238.Acamemic press, New York.

Chhabra, ML B., K. Sinha, D. Singh, K. Dhawan and R. Sharma (2007). Physiological constraints to productivity in Indian mustard (B. juncea L.). In: Tingdong $\mathrm{Fu}, \quad$ ChunyunG (eds): sustainable development in cruciferous oilseed crops production. Proceeding of the $12^{\text {th }}$ international rapeseed congress. Hubei, Wuhan, China.

Egilla, J.N., F.T. Jr. Davies and M.C. Drew (2001). Effect of potassium on drought resistance of Hibiscus rosa-sinensis cv. Leprechaun: plant growth, leaf macro and micronutrient content and root longevity. PI. Soil. 229:213-224.

El-Fouly, M.M., A.I. Rezk, O.A. Nofal and E.A.A. Abou El-Nour (2012). Depletion of magnesium in Egyptian soils, its content in crops and estimated needs. J. Agric. Res., 1(1): 1 -8.

El-Morshedy, F.A. (1997). Studies on fertilization regimes of peach. J. Agric. Res. Tanta Univ., 23(4): 395-412.

El-Sabrout, M.B. and H. A. Kassem (2002). Effect of fertilization with nitrogen and potassium on vegetative growth, yield and leaf mineral content of "Washington" Navel orange trees grown in sandy soil. J. Adv. Agric. Res.7(3):539-553.

El-Safty, M.A. and R.S. Rabii (1998). Effect of foliar and soil application of magnesium sulfate on mineral composition, yield and fruit quality of Washington Navel orange trees. J. Agric. Sci. Mansoura Univ., 23(6): 2635-2641. 
El-Sammak, A.F. and M.A. Zayan (1988). Responce of Baladi mandarin trees under long irrigation period to mineral fertilization. J. Agric. Res. Tanta Univ.,14(2): 906-923.

EL-Seginy, M. (2006). Response of "Canino"Apricot Trees to Different Irrigation and Potassium Treatments. Alex. Sci. Exchange J. vol. 27:64-75

El-Seginy, M., S.M. Malaka Naiema and W.M. Abd El-Messeih (2003). Response of "Anna" apple trees grown in newly reclaimed calcareous soil to magnesium sulfate application in different quantities and doses. Alex. J. Agric. Res., 48: 6974.

El-Shereif, A.R. (1998). Studies on water relation and drought resistance of some Grape varieties. M.S. Thesis, Fac. Of Agric. Kafr El-Sheikh Tanta Univ., Egypt.

El-sherif, H.M., N.M. Taha and F.M. ElFahkarani (2008). Effect of potassium fertilizer source on tree fruiting, fruit quality and storability of "Golden Japanese" plum. Journal of Agricultural Science Mansoura University. 33(4):2743-2756.

Evenhuis, B. and P.W. DeWaard (1980). Principles and practices in plant analysis . F.A.O. Soil bull. 39(1):152-162.

Fanaei, H.R., M. Galavi, M. Kafi and A Ghanbari Bonjar (2009). Ameliorationof water stress by potassium fertilizer in two oil seed species. International Journal of Plant Production , 3 (2):41-54

Farag, K.M. and N. M.N. Nagy (2012). Effect of pre- and post-harvest calcium and magnesium compounds and their combination treatments on "Anna" apple fruit quality and shelf life. J. Hort. Sci. \& Ornamen. Plants, 4 (2): 155-168.

Fathi, M.A., B.A. Shahin and G.I. Eliws (1999). Screening of some deciduous fruit rootstock for relative drought resistance. J. Agric. Sci., Mansoura Univ.,24(6): 351-360.

Fawzi, M. I. F., F.M. Shahin, A. Elham Daood and E.A. Kandil (2010). Effect of organic, biofertilizers and magnesium sulfate on growth, yield, chemical composition and fruit quality of "Le Conte" pear trees. Nature and Science, 8(12): 273-280.

Ferree, D.C. and C.G. Forshey (1988). Influence of pruning and urea sprays on growth and fruiting of spur-bound 'Delicious' apple trees, J. Amer. Soc. Hort. Sci. 113:699-703.

Gomez, K.A. and A.A. Gomez (1984). Statistical procedures for the agricultural researches. John Wiley and Sons Inc., New York.

Hussein, S.M.M. (1998). Influence of irrigation levels on growth, mineral content and fruit quality of "Anna" apple. M.Sc. Thesis, Fac. Agric., Cairo Univ., Egypt.

Jackson, N. L. (1967). Soil Chemical Analysis. Prentice. Hall Inc. Englewood Cliffs, New Jersy.

Jaroszewska, A. (2015). The effect of irrigation and mineral fertilization on the photosynthetic activity and water use in respect of cherry cv. "Kelleris 16" yielding. Acta Sci. Pol. Hortorum Cultus, 14(5) 109 - 120.

Jones, I.B., B. Wolf and H.A. Milles (1991). Plant analysis handbook. Micro-Macro Publishing Inc., pp: 213.

Kassem, H.A. and Amal M. El-Seginy (2002). Response of "Florda Prince" peach trees to soil and foliar application of potassium J. Adv. Agric. Rec. 7 (1): 103-115 Fac. Agric. Saba Bacha, Alex., Egypt.

Khalil, M.A., W.I. Miseha and G. M. Gad ELRab (2000). Water management for apple trees under drip irrigation. J. Agric. Sci. Mansoura Univ., 25(6): 3641-3659.

Khalil, M.A. (1991). Effect of irrigation and potassium fertilization on growth and yield of tomato. M.Sc., Fac. Agric., Swiss Canal Univ.

Kilany, A.E. and O.A. Kilany (1991). Effect of potassium and boron nutrients on growth, yield and fruit quality of "Anna" apple trees. Bull. Fac. Agric., Cairo Univ., 42(2): 415-428. 
Klute, A. (1986). Water Retention; Laboratory Methods .In: A. Koute (ed.) methods of soil Analysis ,Part 1-2 nd ed. Agron .Monogr,9,ASA.,Madison W,U.S.A., PP:635-660

Marschner, H. (1994). Mineral nutrition in higher plants. Academic press, Harcout Brace. Jovanvish Publisher, pp. 6-74

Marschner, H. (1995). Functions of mineral nutrients: Macronutrients. In: Mineral Nutrition of Higher Plants 2 Edition, $\mathrm{H}$. Marschner (Ed.). Academicnd Press, N.Y, pp: 299-312.

Massonnet, C., C. Evelyne, R. Serge, D. Erwin and J.L. Regnard (2007). Stomatal regulation of photosynthesis in apple leaves: Evidence for different water-use strategies between two cultivars. Ann. Bot. 100:1347-1356.

Medrano, H., J. Flexas and J. Gaalmes (2009). Variability in water use efficiency at the leaf level among Mediterranean plants with different growth forms. Plant Soil, 317: 17-29.

Mikhael, G.B. (2007). Effect of some drip irrigation and mulching treatments on: 1Vegetative growth and nutritional status of "Anna" apple trees grown in new reclaimed soils. Minufiy J. Agric. Res., 32(4): 1155-1174.

Mikhael, G.B.Y., Manal A. Aziz and W. M. Abd El-Messeih (2010). Effect of some flood irrigation and potassium fertilization treatments on vegetative growth, yield and fruit quality of "Dessert red" peach trees grown in clay soil. J. of Plant Production, Vol. 1 (4): 599 - 620.

Mohamed, M.S. (2003). Response of Picual and chemical olive trees, grown under two levels of irrigation, to NK fertilization.

Mosa, W.F.A., Nagwa A. Abd EL-Megeed and Lidia Sas Paszt (2015). The effect of the foliar application of potassium, calcium, boron and humic acid on vegetative growth, fruit set, leaf mineral, yield and fruit quality of "Anna" apple trees. American J. of Exp. Agric., 8 (4): 224-234.
Mostafa, E.A.M., M.M.S. Saleh and M.M.M. El-Migeed (2007). Response of banana plants to soil and foliar application of magnesium. American Eurasian J. Agric. \& Environ. Sci., 2(2): 141-146.

Mpelasoka, B.S., M.H. Behboudian and T.M. Mills (2001). Water relations, photosynthesis, growth, yield and fruit size size of "Braeburn" apple: response to deficit irrigation and to crop load. J. of Hort. Sci., \& Biotechnology, 76(2): 150156.

Murphy, J. and J. P. Riley (1962). A modified single solution method for the determination of Phosphorus in natural water .Anal. Chemi. Acta. 27:13-36.

Nawar, A. and E. Thanaa (1993). Leaf relative water content, growth and carbohydrate metabolism in apricot seedlings grown under different soil moisture levels. Alex. J. Agric. Res. 38(1):337-353.

Pasban Eslam, B., M.R. Shakiba, M.R. Neyshabori, M. Moghaddam and M.R. Ahmadi (2000). Evaluation of Physiological Indices as a Screening Technique for Drought Resistance in Oilseed Rape. Pak. Acad. Sci. J. 37(2): 143-152.

Rabino, L. L., Alberto and M.K. Monrad (1977). Photocontrol of anthocyanin synthesis. Journal of plant Physiology.59: 569- 573.

Reddya, A.R., K.V. Chaitanya and M. Vivekanandanb (2004). Drought induced responses of photosynthesis and antioxidant metabolism in higher plants. J. PI. Physiol. 161:1189-1202.

Salama, A.S.M., M. El- Sayed and A.A. Abdel-Hameed (2014). Effect of Magnesium Fertilizer Sources and Rates on Yield and Fruit Quality of Date Palm cv. Hayany under Ras-Sudr Conditions. Research J. of Agric. And Biol. Sci., 10(2):118-126.

Salem, S.E. (2007). Study the interaction effect of potassium and magnesium on yield and quality of grape vine in 
calcareous soils. M.Sc. Thesis Fac. Agric., Alex. Univ. Egypt., pp: 172.

Soliman, M.A. (2003). Effect of foliar spray nutrients on water relationships of some young deciduous fruit trees. M.Sc. Thesis, Fac. Agric., Kafr elsheikh, Tanta Univ., Egypt.

Spiegel-Roy, P. and E. Goldschmidt (2008). Biology of citrus. Combridge University Press, pp: 140-184.

Umar, S. and Moinuddin (2002). Genotypic differences in yield and quality of groundnut as affected by potassium nutrition under erratic rainfall conditions. J. PI. Nutr. 25: 1549-1562.

Vafaie, A., A. Ebadi, B. Rastgou and S. H. Moghadam (2013). The effect of potassium and magnesium on yield and some physiological traits of Safflower
(Carthamus tinctorius) Intl J Agri. Crop Sci. Vol., 5 (17), 1895-1900.

Yadav, D. S., A. K. Goyal and B. K. Vats (1999). Journal of Potassium Research, 15 (1-4), 131-134.

Yin, X., X. L. Huang and J. Roux (2012). Effects of integrated nitrogen fertilization and irrigation systems, rootstocks and cultivars on productivity, water and consumption and mineral nutrition of pear. Agric. Sci., 3(2): $257-267$.

Zayan, M.A., M.M. El-Mogy and G.B. Mikhael (2006). Vegetative growth and yield of Thompson seedless grapevines as affected by NPK fertilization and application of some soil amendments agnts. J. Agric. Sci. Mansoura Univ., 31(4): 2239-2252. 


\section{تأثير الرش بالبوتاسيوم والماغنسيوم على الحالة الغذائية والإنتاجية وجودة الثمار لأثجار التفاح "صنف آنا" تحت ظروف النقاعت النقص المائي}

\section{محمد على محمد سليمان ، هشام محمد عبدالحميد أبوعجيله}

مركز البحوث - معهد بحوث البساتين الزراعية - الجيزة - مصر

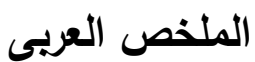

أجريت هذه الدراسة خلال موسمي 2015 و 2016 في مزرعة خاصة بمنطقة النوبارية - بحيرة - مصر بهدف دراسة

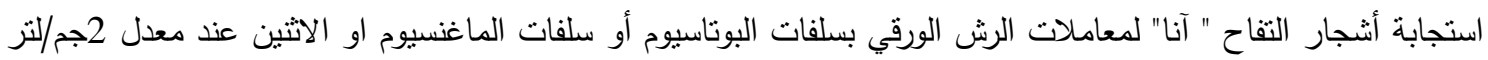

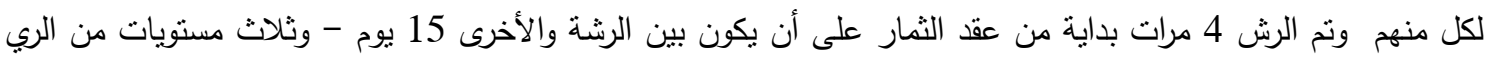

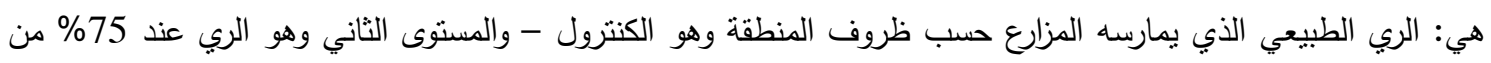

الكنترول - والمستوى الثالث وهو الري عند 50\% من الكنترول ,ويمكن تلخيص أهم النتائج المتحصل عليها فيما يلي:

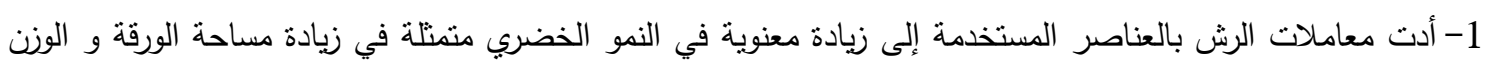

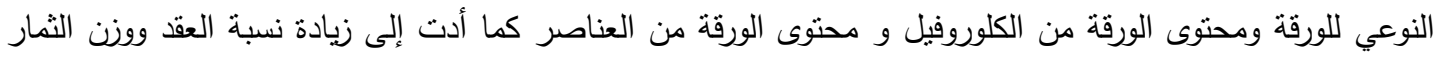

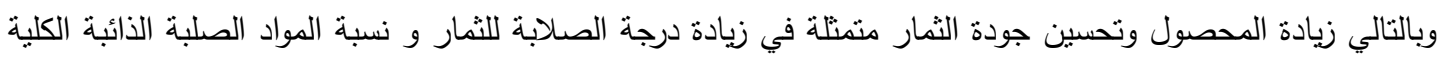

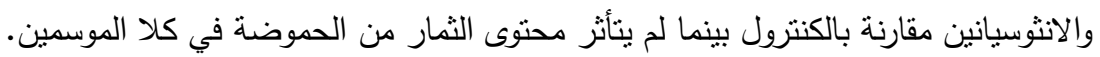
2-سجلت الأشجار المعاملة بالبوتاسيوم و الماغنسيوم أعلى القيم بالنسبة للصفات السابقة مقارنة بنلك المعاملة بالبوتاسيوم

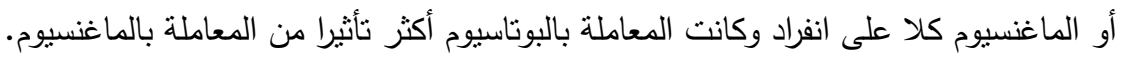

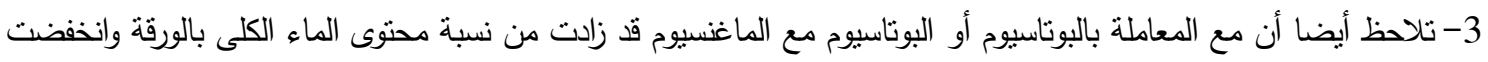
نسبة النقص المائي في الأوراق وفى المقابل أدت المعاملة بالماغنسيوم إلى خفض محتوى الماء الكلى في الأوراق. 4- كما بينت النتائج إن المعاملة الأولى من الري (الكنترول) قد أدت إلى زيادة معنوية في النمو الخضري متمثنا في زيادة

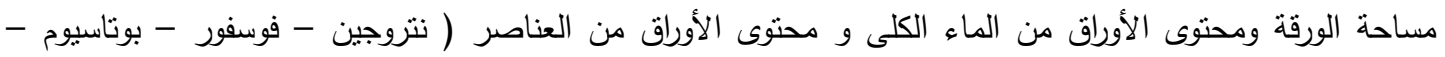
ماغنسيوم) كما أدت إلى زيادة نسبة العقد وزيادة وزن الثمرة و المحصول معبرا عنه كجم/شجرة أو طن/فدان الأن مقارنة

$$
\text { بالمعاملات الأخرى في كلا الموسمين. }
$$

5- سجلت المعاملة الثانية وهى الري عند 75\%من الكنترول زيادة معنوية في الوزن النوعي للورقة (في الموسمين) والمواد

$$
\text { الصلبة الكلية الذائبة (في الموسم الثاني). }
$$

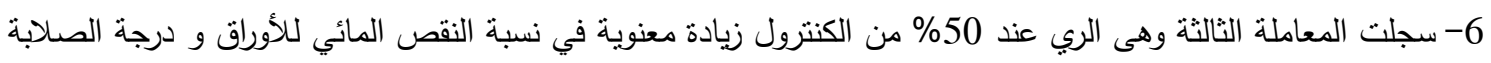
للثمار وقيمة الانثوسيانين في قثرة الثمار في كلا الموسمين ، وزيادة معنوية في نسبة المواد الصلبة الذائبة الكلية في في

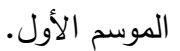
7- أعطت نتائج التفاعل بين معاملات الرش الورقي بالمغذيات والري تحت مسنوى الري الطبيعي (الكنترول) أعلى قيم

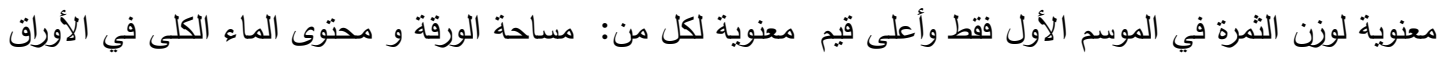

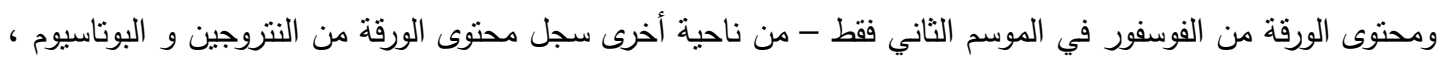
و كمية المحصول معبرا عنه بالكجم/شجرة أو طن/فدان زيادة الفيادة معنوية في كلا الموسمين.

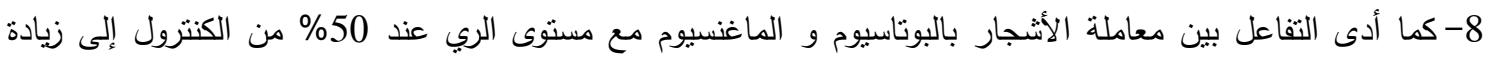

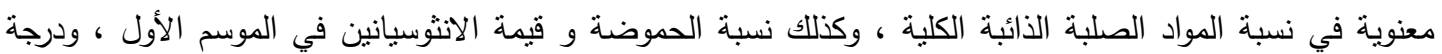
صلابة الثمار في الموسم الثاني 